\title{
FEATURE Rented farmland: A missing piece of the nutrient management puzzle in the Upper Mississippi River Basin?
}

Yuta J. Masuda, Seth C. Harden, Pranay Ranjan, Chloe B. Wardropper, Collin Weigel, Paul J. Ferraro, Sheila M.W. Reddy, and Linda S. Prokopy

$\mathrm{n}$ the United States, agricultural runoff is the leading contributor of nutrient pollution in the Upper Mississippi River Basin, causing environmental impacts, including a large hypoxic zone in the Gulf of Mexico (Rabotyagov et al. 2014). In an attempt to decrease these impacts, government agencies and nonprofit organizations invest billions of dollars annually promoting and paying for conservation practices (e.g, Agriculture Improvement Act of 2018 [H.R. 2, 115th Congress, 2018]). Many of the programs through which these funds are administered may miss the mark because they are not tailored for an important and influential stakeholder for redressing the problem-the person who owns the farmland.

Agricultural runoff is a global issue in an age where commodity crop monocultures and maximized yields are incentivized culturally and economically. Higher crop yields require additional inputs to the system, especially nutrients to supplement degraded soil. These applied nutrients lead to negative consequences for drinking water and aquatic systems during precipitation events. This runoff can be reduced through appropriate conservation practices, such as nitrogen $(\mathrm{N})$ management plans, conservation tillage, buffer strips, and cover crops (Blanco-Canqui et al. 2015; Montgomery 2007). While the costs of implementing these practices are immediate, many of the benefits are in the future and are distributed across the general public. This benefit-cost asymmetry has encouraged governments and nongovernmental organizations (NGOs) to partially or fully subsidize the adoption of conservation practices. Despite substantial increases in total financial payments from the government for practices on working lands, adoption rates remain low on farmland in priority areas for reductions in agricultural runoff (Baranski et al. 2018).

One potentially important factor contributing to low adoption rates is that the marketing and design of conservation

\section{Figure 1}

US counties with the highest level of rented lands and nitrogen $(\mathrm{N})$ yield overlap in the Mississippi River Basin (dark brown counties). Data on rented land acreage were derived from the 2012 Census of Agriculture, and the $\mathbf{N}$ loading data were derived from the US Geological Survey Sparrow Model for the Mississippi River Basin.

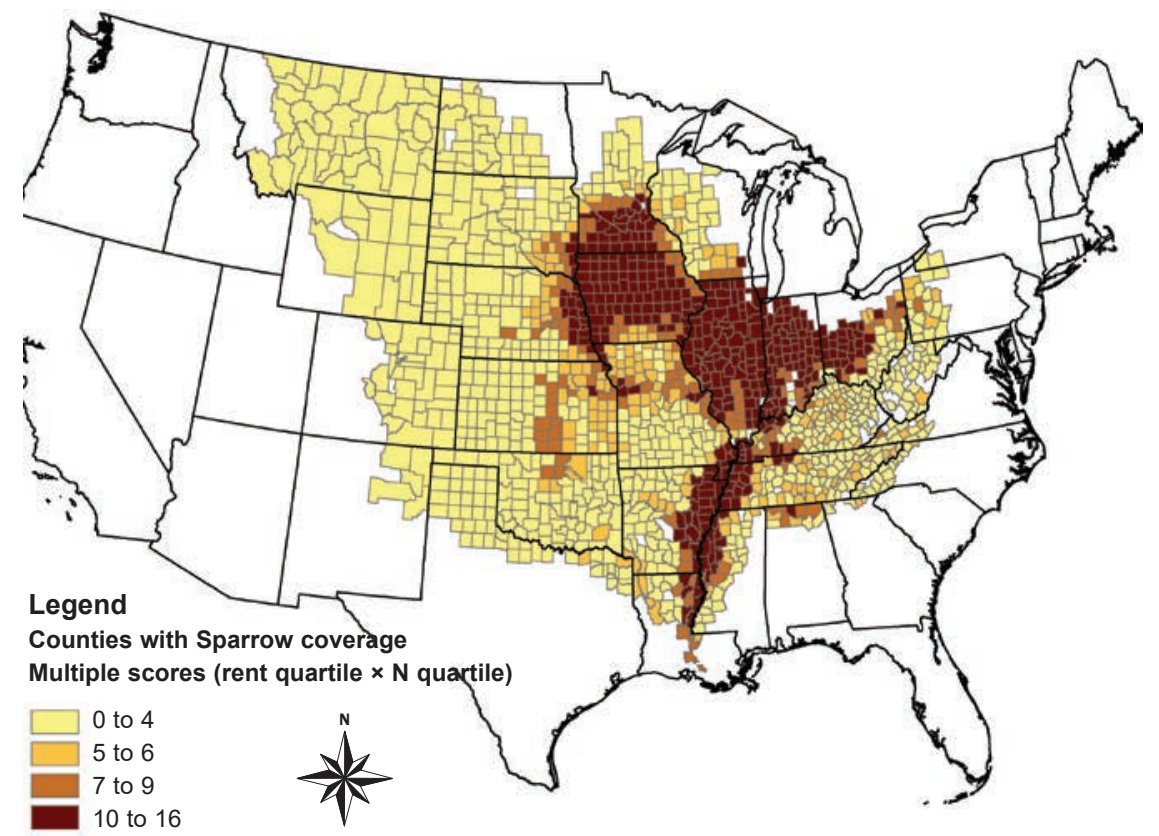

programs may miss key actors. USDA conservation programs are generally targeted at the farmer or "operator," i.e., the person who grows the crops. These operators, however, are often not the same people who own the land. In the United States, $39 \%$ of farmland - about 143 million ha (354 million ac) - is rented (Bigelow et al. 2016). In the Corn Belt, a high productivity area within the nutrient-polluted Mississippi River Basin, the percentage of rented farmland is even higher, approximately 60\% (figure 1) (Bigelow et al. 2016). In this priority area for nutrient pollution abatement, the majority (87\%) of the landowners who rent land do not themselves farm; i.e., they are nonoperating landowners (NOLs) (Bigelow et al. 2016). Adoption of conservation practices can be lower on rented farms depending on the type of lease arrangement (Soule et al. 2000), and enrollment in land retire-
Yuta J. Masuda is a senior sustainable development and behavioral scientist in the Global Science Division, The Nature Conservancy, Seattle, Washington. Seth C. Harden is the Upper Wabash River Project director at The Nature Conservancy, Indianapolis, Indiana. Pranay Ranjan is a postdoctoral research associate in the Department of Forestry and Natural Resources, Purdue University, West Lafayette, Indiana. Chloe B. Wardropper is an assistant professor in the Department of Natural Resources and Society, University of Idaho, Moscow, Idaho. Collin Weigel is a behavioral economist in the Research Division at the California Air Resources Board, Sacramento, California. Paul J. Ferraro (corresponding author) is the Bloomberg Distinguished Professor in the Carey Business School and the Department of Environmental Health and Engineering, a joint department of the Bloomberg School of Public Health and the Whiting School of Engineering, Johns Hopkins University, Baltimore, Maryland. Sheila M.W. Reddy (corresponding author) is the associate director of strategic initiative in the Chief Conservation Office, The Nature Conservancy, Durham, North Carolina. Linda S. Prokopy (corresponding author) is head and professor in the Department of Horticulture and Landscape Architecture, Purdue University, West Lafayette, Indiana. 
ment programs, such as the Conservation Reserve and Wetland Reserve Programs, is lower among renter operators than owneroperators (Petrzelka et al. 2009).

While there is still more to learn about this heterogeneous group (Bigelow and Hubbs 2016), such as their farming experience and engagement with operators, the fact remains that conservation programs are rarely tailored toward NOLs despite their potential importance in nutrient management. Who owns the land can affect the way it is managed (UlrichSchad et al. 2016; Robinson et al. 2017). In comparison to owner-operators, renting operators have different incentives and barriers shaping their agricultural practices. As we explain below, without accounting for the relationship between NOLs and their operators, conservation practice adoption on NOL-owned farmland may remain low. Instead, if USDA and partners extend the marketing and design of conservation programs to NOLs, the outlook for agricultural pollution abatement in nutrient-laden watersheds may improve.

\section{WHAT CHALLENGES LIMIT WIDESPREAD ADOPTION OF CONSERVATION PRACTICES ON RENTED LANDS?}

USDA programs often focus solely on constraints unique to owner-operators and ignore the overlapping and nonoverlapping priorities, constraints, and preferences of NOLs and their operators. There are three challenges unique to rented land that may limit the adoption of conservation practices: a principal-agent problem, higher transaction costs, and a lack of tailored information to NOLs. These factors exacerbate the challenge of misaligned incentives that is found on all farmland. That is, while the adopters incur the costs of adopting and maintaining conservation practices, many of the benefits from those practices accrue to the public in the form of environmental services.

First, conservation practices on rented lands suffer from a principal-agent, or agency, problem. The operator (agent) makes decisions directly impacting the NOL's (principal's) land, but the operator has little incentive in adopting practices if the private benefits (e.g., through maintaining healthy soil in the long-term) primarily flow to the NOL. These misaligned incentives are exacerbated by a second problem: the NOL cannot easily observe what the operator is doing. Only $18 \%$ of NOLS are involved in making decisions about practices (Bigelow et al. 2016), and thus most NOLs cannot ensure the operator is acting in their interests. Other features of the NOL-operator relationship exacerbate the agency problem. The on-site benefits from conservation practices are often realized over long time horizons, but $70 \%$ of leases are singleyear leases. Even though many leases are renewed annually (Bigelow et al. 2016), the short duration of the lease may create uncertainty about whether the operator will benefit from investing in practices (Ranjan et al. 2019). In addition, many leases do not provide mechanisms to share upfront costs or long-term profits from implementing these practices. Further, the complex social dynamics between NOLs and operators (e.g., extended family or community members, gender differences) likely affect NOLs' comfort levels in dictating farming practices (Petrzelka et al.2020; Barnett et al. 2020). For example, some women landowners have reportedly found it difficult to talk to their male operators about farming practices (Carolan 2005).

Second, the NOL-operator relationship results in transaction costs that are not present for owner-operators, including communicating information about practices or agreeing to apply to government programs and providing the necessary documentation. These transaction costs are amplified by the growing consolidation of US farms over the last three decades, which means operators are renting from an increasing number of landowners (Bigelow et al. 2016).

Third, while both landowners and operators are eligible for government program support, marketing and technical assistance are largely directed at the operator and assumes knowledge about, and involvement in, farm operations. NOLs are often not part of the target audience, especially NOLs who live out-of-state or who do not fit the typical farmer profile, such as women or investors (Petrzelka et al. 2013).

\section{HOW CAN WE DO BETTER?}

Sustainable agriculture programs should be rooted in behavior change frameworks that consider the NOL-operator relationship. Behavior change interventions can be grouped into four categories: promoting awareness and concern, incentives (financial, social, intrinsic), nudges, and regulations (Reddy et al. 2017). We focus most of our recommendations on the first three categories because of challenges associated with regulating nonpoint source pollution from agriculture. While regulations have proven effective for reducing pollution from point sources, they face substantial technical and political challenges in the context of nonpoint source pollution. The technical challenges include tracing diffuse pollutants to their sources. The political challenges stem from a regulatory system that delegates nonpoint source pollution control to state governments, where rural communities reliant on agriculture retain substantial political influence. Even in states like Maryland, where farms are required to follow nutrient management plans, the regulations are accompanied by substantial incentives and technical assistance to encourage the implementation of dozens of conservation practices (Maryland Department of Environment 2019).

Related to the first three intervention categories, figure 2 presents specific interventions according to how the NOL and the operator can advance through five stages of the adoption process (i.e., knowledge, persuasion, decision, implementation, and confirmation or continuation) (Rogers 2003). Interventions should help the NOL and the operator progress through each stage, even if they are starting at different stages.

First, the NOL and operator need to have knowledge about practices. With limited exceptions, programs from the USDA Natural Resources Conservation Service (NRCS), university extension, soil and water conservation districts, and NGOs have traditionally targeted operators, overlooking the fact that NOLs may be less knowledgeable about these practices 


\section{Figure 2}

Barriers and interventions that are particular to the nonoperating landowner (NOL) and operator decision context. This figure depicts five stages or steps of the adoption process as a ladder (Rogers 2003). There are barriers blocking progress at each step; however, there are also interventions that can help overcome each of these barriers. The ladder on the left depicts the barriers faced by owner-operators. The ladder on the right depicts the additional barriers faced by NOLs and operators. The teal arrows on the far right contain examples of the types of interventions that might help address barriers unique to the NOL and operator decision context. Each intervention is categorized by its behavior change approach (promoting awareness [A], incentives [I], and nudges [N]). The steps are illustrated as a ladder that the NOL and operator have to climb together because research strongly suggests that the operator is unlikely to ultimately adopt conservation without some support from their NOL, and the NOL cannot implement conservation alone (Petrzelka et al. 2013; Ulrich-Schad et al. 2016; Ranjan et al. 2019).

\begin{tabular}{lrr}
$\begin{array}{l}\text { Adoption steps } \\
\text { (sensu Rogers) }\end{array}$ & $\begin{array}{c}\text { Barriers to adoption for different decision contexts } \\
\text { Owner-operator }\end{array}$ & $\begin{array}{c}\text { Example interventions for NOLs- } \\
\text { operator decision context }\end{array}$ \\
\hline
\end{tabular}

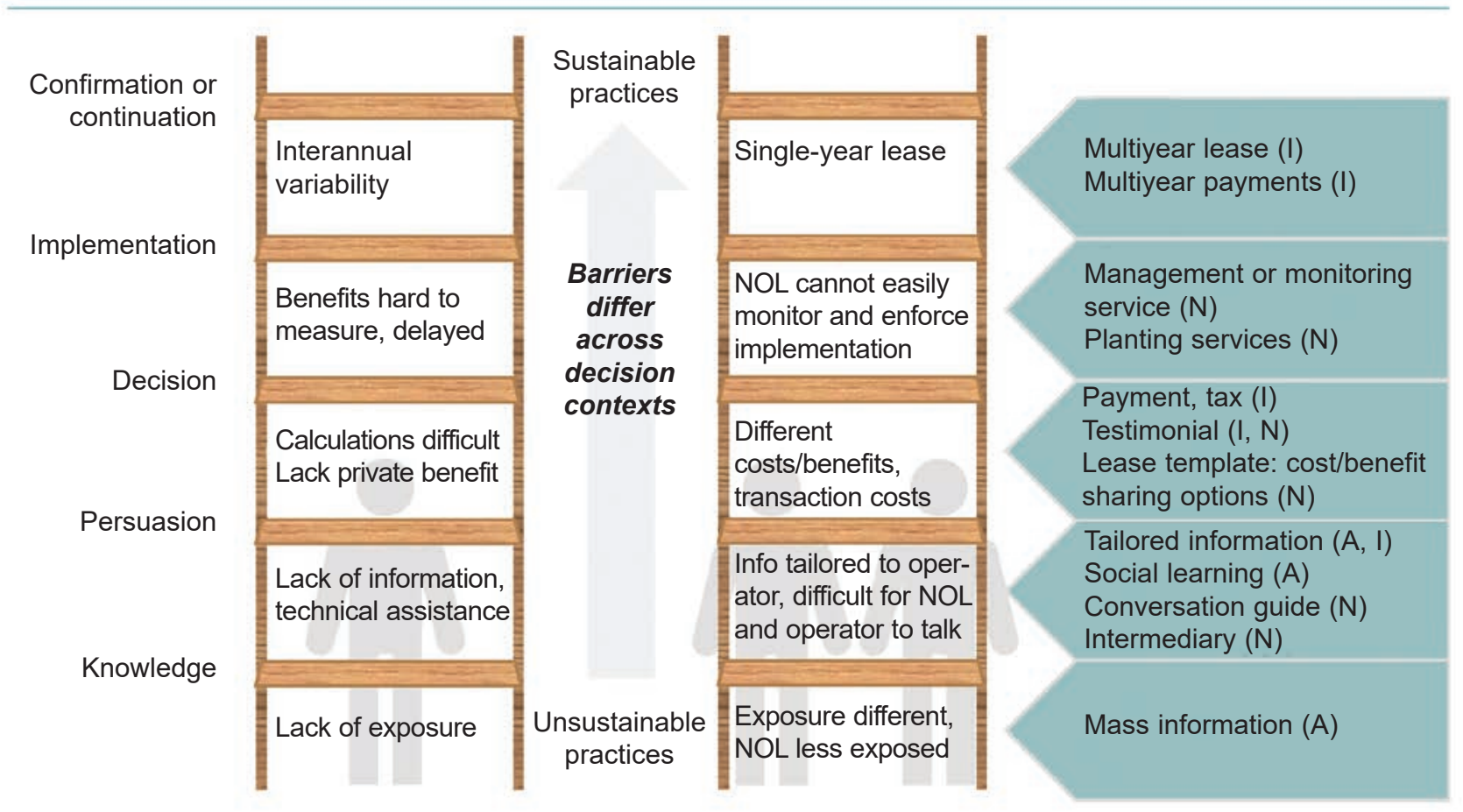

(Petrzelka et al. 2020). Mass information interventions, such as mailers, can increase knowledge amongst NOLs and operators.

Second, NOLs and operators must be persuaded that practices, or the programs providing financial or technical assistance for these practices, have real benefits. Interventions to address this barrier could focus on providing salient information about the benefits from these practices and programs to NOLs and operators in terms that make sense to them, such as data on financial and soil health benefits or credible testimonials from NOLs and operators who have participated in a program or used sustainable practices on rented lands.

Consensus and understanding between NOLs and operators about the costs and benefits of participating in conservation programs or adopting practices is central to the persuasion, decision, and implementation stages of the adoption process. Here, interventions may focus on reducing barriers to communicate effectively about practices between NOLs and their operators, such as through conversation guides or access to intermediaries who can facilitate communication between NOLs and operators.

In the United States, one barrier to communication about conservation practices is USDA's power of attorney form. With a single signature from the NOL, federal agencies can bypass the NOL and go directly to the operator with information and incentive opportunities. With no explanation of the implications from signing the form, nor any option to request communication about programs that provide technical assistance and financial incentives, the form discourages NOLs and operators from working collaboratively to choose conservation practices.

Finally, in the move from the decision to implementation stage, a barrier hindering adoption by operators is the uncertainty that is a feature of many lease terms. Here, interventions may focus on nudging behavior, providing technical assistance, and distributing financial incentives to cover transactions costs and operational costs to reduce risks to the NOL and operator. While not all renter operators in annual leases experience uncertainty, which may vary by annual contract type (Allen and Lueck 1993; Soule et al. 2000; Bigelow et al. 2016), there are opportunities to address uncertainty, misalignment 
in incentives, or other barriers created by lease terms.

Some of these opportunities are already being pursued. For example, NRCS and the Soil Health Partnership recently published testimonials from diverse stakeholders to persuade skeptical NOLs and operators, and NRCS provides guidance for NOLs to talk with their operators (USDA NRCS 2019). Our own efforta university-NGO collaboration-used large randomized controlled trials to test different messages in a mass mailing campaign and different forms of conservation assistance (e.g., information, lease language, financial payments) targeting NOLs (Reddy et al. 2020). The American Farmland Trust collaborated with the Women Food and Agriculture Network and NRCS to implement women's learning circles aimed at helping empower female NOLs to take steps toward conservation by sharing their experiences with peers and getting access to experts (Fairchild et al. 2019). Although these projects have yet to meaningfully change trends in the adoption of practices on rented lands, each project has generated evidence of steps being taken towards conservation actions (e.g., NOLs talking to other family members and tenants, seeking local resources, self-reported adoption of practices).

\section{CALL TO ACTION}

A recent call to action for sustainable agriculture from NGO and academic representatives focused on increasing funding in the United States (DeLonge et al. 2016). This additional funding should be used to improve the design and implementation of conservation programs targeting rented lands within the Upper Mississippi River Basin and other priority areas, such as the Chesapeake Bay. First, USDA ought to reevaluate the power of attorney forms that encourage conservation programs to ignore NOLs in favor of operators. Second, USDA and its partners need to design conservation outreach materials specifically for NOLs, building on research that elucidates what messages resonate with this group (Reddy et al. 2020). Targeted materials would address the very different incentives and constraints that NOLs face relative to operators. Third, the types of assistance offered by conservation programs need to be designed with rented lands in mind. Given misaligned incentives, programs will need to find creative ways to help operators and NOLs to share the upfront costs and the long-run benefits from implementing conservation practices. As in other contexts with misaligned incentives (e.g., energy efficiency investments in rented buildings), new regulations may be needed to augment voluntary programs (Reddy et al. 2017). Given the higher transaction costs of conservation on these lands, higher incentive payments or more intensive technical assistance packages may also be necessary. Regardless, actions addressing low adoption of conservation practices on rented lands should be done hand-in-hand with those targeting owner-operators. Overall, adoption of conservation practices remains low.

Ultimately, to determine which policies and program designs will be most effective, we need field testing. Sustainable agriculture has a rich history of experimental research about practices and descriptive research about operators, but it does not have a culture of program experimentation. That needs to change. Development and testing of new designs should be inclusive and collaborative, and include NOLs, operators, universities, NGOs, private sector actors, and local and federal agencies. To ensure that testing catalyzes sustainable agricultural adoption, these collaborators need to leverage their comparative advantages. Nongovernmental actors are nimbler and more flexible than government agencies and thus are positioned to rapidly test hypotheses and mechanisms through which effective programs and practices can be quickly scaled up. Local, state, and federal government agencies should be partners in these efforts and engaged as end users. Researchers must allocate greater effort to comprehensively evaluate barriers to program implementation, as well as assess program impacts. Local, state and federal legislators must advance legislation (e.g., through the farm bill) that creates incentives for experimentation, iteration, and the refinement of existing policies, as well as the development of new policies.
While little is known about NOLs outside the United States, we posit that this call to action applies to high-income countries globally. Nutrient pollution is a problem worldwide (Steffen et al. 2015), and many high-income countries have high rates of rented agricultural lands and growing populations of NOLs (Toman et al. 2019). The challenges that NOLs create for conservation success are likely to be similar in these countries.

Targeting NOLs will not, by itself, solve the environmental problems created by agriculture. NOLs are just one group in the broader policy landscape, and NOLs are themselves diverse. Yet their influence over agricultural lands is growing. They must be included in the policy landscape if we are to attain a future where food production is maintained, waters and lands are sustainably managed, and people and the planet are thriving.

\section{ACKNOWLEDGEMENTS}

Ferraro acknowledges funding from USDA Economic Research Service (\#59-6000-4-0064) and USDA National Institute of Food and Agriculture (\#2019-67023-29854). All authors benefited from external and internal advisors throughout the project. The project was funded by a generous anonymous donation to The Nature Conservancy.

\section{REFERENCES}

Allen, D.W., and D. Lueck. 1993. Transaction costs and the design of cropshare contracts. The RAND Journal of Economics 24(1):78. https:// doi.org/10.2307/2555954.

Baranski, M., H. Caswell, R. Claassen, C. Cherry, K. Jaglo, A. Lataille, S. Pailler, et al. 2018. Agricultural Conservation on Working Lands: Trends From 2004 to Present. Technical Bulletin Number 1950. Washington, DC: USDA. http://www.ascr. usda.gov/complaint_filing_cust.html.

Barnett, M.J., K. Spangler, P. Petrzelka, and J. Filipiak. 2020. Power dynamics of the non-operating landowner-renter relationship and conservation decision-making in the midwestern United States. Journal of Rural Studies 78(January):107-14. https://doi.org/10.1016/j.jrurstud.2020.06.026.

Bigelow, D., A. Borchers, and T. Hubbs. 2016. U.S. Farmland Ownership, Tenure, and Transfer. Washington, DC: USDA Economic Research Service. https://www.ers.usda.gov/webdocs/ publications/74672/eib-161.pdf? $\mathrm{v}=7725.9$. 
Bigelow, D., and T. Hubbs. 2016. Land Acquisition and Transfer in U.S. Agriculture. Amber Waves, August 25, 2016.

Blanco-Canqui, H., T.M. Shaver, J.L. Lindquist, C.A. Shapiro, R.W. Elmore, C.A. Francis, and G.W. Hergert. 2015. Cover crops and ecosystem services: Insights from studies in temperate soils. Agronomy Journal 107(6):2449-74. https://doi. org/10.2134/agronj15.0086.

Carolan, M.S. 2005. Barriers to the adoption of sustainable agriculture on rented land: An examination of contesting social fields. Rural Sociology 70(3):387-413. https://doi. org/10.1526/0036011054831233.

DeLonge, M.S., A. Miles, and L. Carlisle. 2016. Investing in the transition to sustainable agriculture. Environmental Science and Policy 55(1):266-273. https://doi.org/10.1016/j. envsci.2015.09.013.

Fairchild, E., M. Briggs-Ott, and P. Petrzelka. 2019. Testing the Women Landowner Conservation Learning Circle Model. Washington, DC: American Farmland Trust.

Maryland Department of Environment. 2019. Maryland's Phase III Watershed Implementation Plan to Restore Chesapeake Bay by 2025. Baltimore, MD: Maryland Department of the Environment.

Montgomery, D.R. 2007. Soil erosion and agricultural sustainability. Proceedings of the National Academy of Sciences 104(33):13268-72. https:// doi.org/10.1073/pnas.0611508104.

Petrzelka, P.,T. Buman, and J. Ridgely. 2009. Engaging absentee landowners in conservation practice decisions: A descriptive study of an understudied group. Journal of Soil and Water Conservation 64(3):94A-99A. https://doi.org/10.2489/ jswc.64.3.94A.

Petrzelka, P., J. Filipiak, G. Roesch-Mcnally, and M.J. Barnett. 2020. Understanding and Activating Non-Operator Landowners: Non-Operator Landowner Survey Multi-State Report. Washington, DC: American Farmland Trust.

Petrzelka, P., Z. Ma, and S. Malin. 2013. The elephant in the room: Absentee landowner issues in conservation and land management. Land Use Policy 30(1):157-66. https://doi.org/10.1016/j. landusepol.2012.03.015.

Rabotyagov, S.S., T.D. Campbell, M. White, J.G. Arnold, J.Atwood, M.L. Norfleet, C.L. Kling, P.W. Gassman, A.Valcu, and J. Richardson. 2014. Costeffective targeting of conservation Investments to reduce the northern Gulf of Mexico hypoxic zone. Proceedings of the National Academy of Sciences 111(52):18530-18535.

Ranjan, P., C.B. Wardropper, F.R. Eanes, S.M.W. Reddy, S.C. Harden, Y.J. Masuda, and L.S.
Prokopy. 2019. Understanding barriers and opportunities for adoption of conservation practices on rented farmland in the US. Land Use Policy 80(February 2018):214-23. https://doi. org/10.1016/j.landusepol.2018.09.039.

Reddy, S.M.W., J. Montambault, Y.J. Masuda, E. Keenan, W. Butler, J.R.B. Fisher, S.T. Asah, and A. Gneezy. 2017. Advancing conservation by understanding and influencing human behavior. Conservation Letters 10(2):248-56. https://doi. org/10.1111/conl.12252.

Reddy, S.M.W., C.Wardropper, C.Weigel,Y.J. Masuda, S. Harden, P. Ranjan, J.M. Getson, L.A. Esman, P. Ferraro, and L. Prokopy. 2020. Conservation behavior and effects of economic and environmental message frames. Conservation Letters, August. https://doi.org/10.1111/conl.12750.

Robinson, B.E., Y.J. Masuda, A. Kelly, M.B. Holland, C. Bedford, M. Childress, D. Fletschner, et al. 2017. Incorporating land tenure security into conservation. Conservation Letters 11(2):e12383. https://doi.org/10.1111/conl.12383.

Rogers, E.M. 2003. Diffusion of Innovations. 3rd ed. New York: Collier Macmillan. https://doi. org/82-70998.

Soule, M.J., A. Tegene, and K.D. Wiebe. 2000. Land tenure and the adoption of conservation practices. American Journal of Agricultural Economics 82(4):993-1005. https://doi. org/10.2307/1244536.

Steffen, W., K. Richardson, J. Rockström, S.E. Cornell, I. Fetzer, E.M. Bennett, R. Biggs, et al. 2015. Planetary boundaries: Guiding human development on a changing planet. Science 348(6240):1217-1217. https://doi.org/10.1126/ science.aaa9629.

Toman, E., A.L. Curtis, and E. Mendham. 2019. Same as it ever was? Stability and change over 15 years in a rural district in southeastern Australia. Society \& Natural Resources 32(1):113-32. https://doi. org/10.1080/08941920.2018.1505014.

Ulrich-Schad, J.D., N. Babin, Z. Ma, and L.S. Prokopy. 2016. Out-of-state, out of mind? Non-operating farmland owners and conservation decision making. Land Use Policy 54:602-13. https://doi. org/10.1016/j.landusepol.2016.02.031.

USDA NRCS (Natural Resources and Conservation Service). 2019. Soil Health: Unlock the Secrets in the Soil. Washington, DC: USDA Natural Resources Conservation Service. https://www. nrcs.usda.gov/wps/portal/nrcs/main/national/ soils/health/. 